\title{
Mangelfull overvåking av skadedødsfall i norsk landbasert arbeidsliv
}

\author{
Ebba Wergeland ${ }^{1}$, Finn Gjertsen ${ }^{2}$ og Johan Lund ${ }^{3}$ \\ 1) Arbeidstilsynet, Postboks 8174 Dep, 0034 Oslo \\ 2) Folkehelseinstituttet, Postboks 4404 Nydalen, 0403 Oslo \\ 3) Helsedirektoratet, Postboks 7000 St. Olavs plass, 0130 Oslo \\ Korrespondanse: Ebba Wergeland, telefon:+4790070732 e-post: ebba-we@online.no
}

\section{SAMMENDRAG}

Bakgrunn: I en tidligere studie av Arbeidstilsynets registreringer av arbeidsskadedødsfall 2000-2003 identifiserte vi - med supplering fra SSB (Dødsårsaksregisteret) - i alt 214 dødsfall i landbasert arbeidsliv blant bosatte i Norge. Av disse var $171(80 \%)$ registrert i Arbeidstilsynet. Komplettheten varierte med næring og skadetype slik at suppleringen endret risikobildet. I denne studien har vi brukt NAVs yrkesskadedata og forsikringsselskapenes yrkesskaderegister DAYSY for å undersøke om ytterligere arbeidsskadedødsfall kunne identifiseres.

Metode: Yrkesskadesaker fra NAV og DAYSY med skadedato 2000-2003 og død innen ett år, ble gjennomgått og sammenholdt på individnivå med opplysninger i Dødsårsaksregisteret.

Resultater: 32 nye arbeidsskadedødsfall ble identifisert. Gjennomsnittsalderen var lavere enn for de opprinnelige 214 (37 vs 46 år). Andelen dødsfall på grunn av transportulykker med personbil (ICD-10 V40-V49) var høyere (41 vs 10\%). Av de tilsammen 246 identifiserte dødsfall hadde Arbeidstilsynet registrert $70 \%$, NAV 64\%, Dødsårsaksregisteret 57\% og DAYSY 20\%.

Fortolkning: Tilleggsinformasjon fra NAV og DAYSY endret lite på det opprinnelige risikobildet basert på informasjon fra Arbeidstilsynet og Dødsårsaksregisteret. Økningen i totalantallet stemte med vårt estimat basert på to datakilder. Manglende registrering i NAV og DAYSY kan delvis skyldes at det ikke var fremmet krav fra etterlatte om yrkesskadeytelser.

\section{Wergeland E, Gjertsen F, Lund J. Inadequate surveillance of fatal occupational injuries in Norwegian land} based activities. Nor J Epidemiol 2016; 26 (1-2): 117-123.

\section{ENGLISH SUMMARY}

Background: In a previous study of fatal occupational injuries 2000-2003 registered by the Norwegian Labour Inspection Authority (NLIA) and supplemented from Statistics Norway (the Cause of Death Registry, CDR), we identified a total of 214 deaths in land based industries among residents in Norway. From these, $171(80 \%)$ had been registered by the NLIA. The completeness in the NLIA register varied according to industry and type of injury, so that supplementing from CDR altered the distribution of risk. In the present study we have supplemented with two other data sources - the National Insurance Administration (NIA) and Finance Norway (FN) for private insurance companies - in order to see if further deaths from occupational injuries could be identified. Method: Cases of occupational injuries from NIA and FN with date of injury 2000-2003 and death within one year, were scrutinized and compared individually with information in the CDR by means of their unique personal identification number.

Results: 32 new cases of fatal occupational injuries were identified. The average age was lower than for the original 214 (37 vs 46 years). The proportion of deaths of car occupants in transport accidents (ICD-10 V40V49) was higher (41 vs 10\%). Due to the small number added, the overall risk distribution remained the same. Of the total 246 deaths identified, the NLIA had registered $70 \%$, NIA $64 \%$, CDR $57 \%$ and FN $20 \%$.

Interpretation: The additional information from NIA and FN did not markedly alter the risk distribution based on information from NIA and CDR. The increase in total number of registered deaths from four sources was in accordance with our estimated number based on two sources. Some of the incompleteness in registration by NIA and FN indicates that not all the bereaved that were entitled to occupational injury compensation, had made such request.

This is an open access article distributed under the Creative Commons Attribution Licence, which permits unrestricted use, distribution, and reproduction in any medium, provided the original work is properly cited.

\section{INNLEDNING}

Årlig registrerer Arbeidstilsynet 40-50 arbeidsskadedødsfall (1). Antallet har vært relativt stabilt siden 2001. Samtidig antar Arbeidstilsynet at rapporteringen er blitt bedre de seneste årene, noe som kan innebære at risikoen er redusert. På bakgrunn av disse registreringene kan det imidlertid heller ikke utelukkes at den generelle dødsrisikoen er på samme nivå i dag som for femten år siden, eller til og med høyere.

Dødsfall etter arbeidsskader er den potensielt mest presise indikatoren for alvorlige personskader i 
arbeidslivet. Skader som fører til varig mén og andre alvorlige, men ikke-dødelige skader er vanskeligere å definere og telle. Traumatiske amputasjoner er ett av få unntak. Det er påvist mangler i statistikken over arbeidsskadedødsfall og arbeidsrelaterte traumatiske amputasjoner $(2,3)$. Det innebærer manglende oversikt over risikoen for alvorlige personskader i arbeidslivet.

Endringer i antall dødsfall over tid kan skyldes endringer $i$ rapporteringen og $i$ forhold som endrer sjansen for å overleve, som bedre medisinsk behandling og transport. Behandlingstilbudet er viktig, men det er først og fremst primærforebyggende tiltak som kan redusere antall dødsfall og andre alvorlig personskader (4). Pålitelig statistikk er viktig for prioritering, overvåking og evaluering av det forebyggende arbeidet $(5,6)$. For å avdekke årsaksforhold kreves det i tillegg detaljert informasjon om enkelthendelsene, for eksempel basert på gransking (5).

Vi har tidligere undersøkt Arbeidstilsynets registrering 2000-2003 ved å sammenlikne med Dødsårsaksregisteret i Statistisk sentralbyrå (SSB) (2). Basert på inklusjonskriteriene $i$ Arbeidstilsynets register og Dødsårsaksregisteret påviste vi underregistrering i begge kilder. Arbeidstilsynets statistikk var mest komplett. Alle dødsfallene var registrert i Dødsårsaksregisteret, men ikke som arbeidsskadedødsfall.

Nitti prosent av dødsfallene vi identifiserte inntraff 0-2 dager etter skaden. Internasjonalt defineres arbeidsskadedødsfall (fatal occupational injuries) som dødsfall innen ett år (7). Vi forventet at NAV og forsikringsselskapene ville fange opp flere skader med lang overlevelsestid. Formålet med denne studien var å undersøke om NAV og forsikringsselskaper hadde registrert arbeidsskadedødsfall som ikke var identifisert av Arbeidstilsynet og SSB.

\section{MATERIALE OG METODE}

I vår forrige studie etablerte vi et midlertidig forskningsregister basert på informasjon fra Arbeidstilsynet og SSB (Dødsårsaksregisteret) som omfattet dødsfall etter arbeidsskader i perioden 2000-2003 (2). Arbeidstilsynet registrerer skadedato, men ikke dødsdato. Dødsårsaksregisteret registrerer ikke skadedato, men den står på dødsmeldingen. Dødsfall som bare var registrert i Dødsårsaksregisteret ble gitt skadedato basert på dødsmelding eller tilleggsinformasjon. Registeret inneholdt informasjon om 214 arbeidsskadedødsfall hos personer som var sysselsatt i landbasert virksomhet (Arbeidstilsynets inklusjonskriterium) og bosatt i Norge på dødstidspunktet (Dødsårsaksregisterets inklusjonskriterium). Selvpåførte skader ble ikke inkludert.

Lov om yrkesskadeforsikring pålegger norske forsikringsselskap å føre et register over alle yrkesskader. Siden 1991 har flere forsikringsselskap levert data til et felles register (DAYSY) som ligger i Finans Norge (8). I vår studie har vi benyttet informasjon fra NAV og DAYSY om personer registrert med yrkesskadesak med skadedato 2000-2003 der dødsfallet skjedde innen ett år etter skaden. For å avgjøre om dødsfallet var et

\section{Hovedbudskap}

- Arbeidstilsynet kan vanskelig overvåke risikoutviklingen med dagens statistikk over arbeidsskadedødsfall, uten kunnskap om omfang og fordeling av underrapporteringen.

- Bedre risikoovervåking kan oppnås med forbedringer av Arbeidstilsynets og Dødsårsaksregisterets løpende registreringer.

- Informasjonen om arbeidsskadedødsfall i de to registrene bør valideres periodisk ved sammenlikning på individnivå.

arbeidsskadedødsfall etter Arbeidstilsynets kriterier (2), ble dødsårsak i Dødsårsaksregisteret sammenholdt på individnivå med opplysningene fra NAV og DAYSY om skadetype. Ved behov ble det gjort en samlet vurdering av opplysninger fra dødsmelding, eventuell obduksjonsrapport og fra NAV og forsikringsselskap.

De nye arbeidsskadedødsfallene vi identifiserte på denne måten ble sammenliknet med de opprinnelige 214 for kjønns- og aldersfordeling, tid fra skade til død, dødsårsaker (inkludert skadens medisinske art (kap XIX i ICD-10 (International Classification of Diseases, 10th Revision)) og ytre skadeårsak (kap XX i ICD-10). De fire kildene (Arbeidstilsynet, Dødsårsaksregisteret, NAV og DAYSY) ble også sammenliknet innbyrdes for å se om de fanget opp forskjellige delutvalg.

Vi fikk tilgang til opplysninger om arbeidsstyrkestatus (ansatt/selvstendig/ikke sysselsatt) og næring fra SSB i aggregert form (tabeller). Opplysningene var hentet fra sysselsettingsstatistikk for året nærmest skadetidspunktet. Hvis dette manglet ble opplysning fra henholdsvis lønns- og trekkoppgaveregisteret, Arbeidstilsynets register eller arbeidstakerstatistikken benyttet, i denne rekkefølgen. SSB manglet opplysninger om yrke.

Statistiske analyser ble utført med SPSS (IBM SPSS Statistics version 22). Insidensrater ble beregnet på grunnlag av antall timeverk, antall sysselsatte og antall årsverk etter hovednæring i Statistisk Sentralbyrås statistikk over nasjonalregnskap $(9,10)$. Vi beregnet også risiko som «døde per 1000 yrkesliv», der ett yrkesliv ble satt til 50 årsverk.

Det ble innhentet dispensasjon fra taushetspliktregler for tilgang til personopplysninger fra NAV og DAYSY. Det var tidligere gitt tillatelser fra Datatilsynet og Sosial- og helsedirektoratet for tilgang til personopplysninger fra Arbeidstilsynet og Dødsårsaksregisteret i SSB. Prosjektet er godkjent av Regional komite for medisinsk forskningsetikk i Sør-Norge.

\section{Resultater}

Ved hjelp av de to nye kildene (NAV og DAYSY) identifiserte vi 32 arbeidsskadedødsfall i tillegg til de 214 fra Arbeidstilsynet og Dødsårsaksregisteret. Seks dødsfall var registrert i alle fire kilder, mens 58 bare var registrert $\mathrm{i}$ en kilde, oftest Arbeidstilsynet eller NAV (tabell 1, figur 1). Arbeidstilsynets register var mest komplett med 171 av samtlige 246 (70\%). NAV 


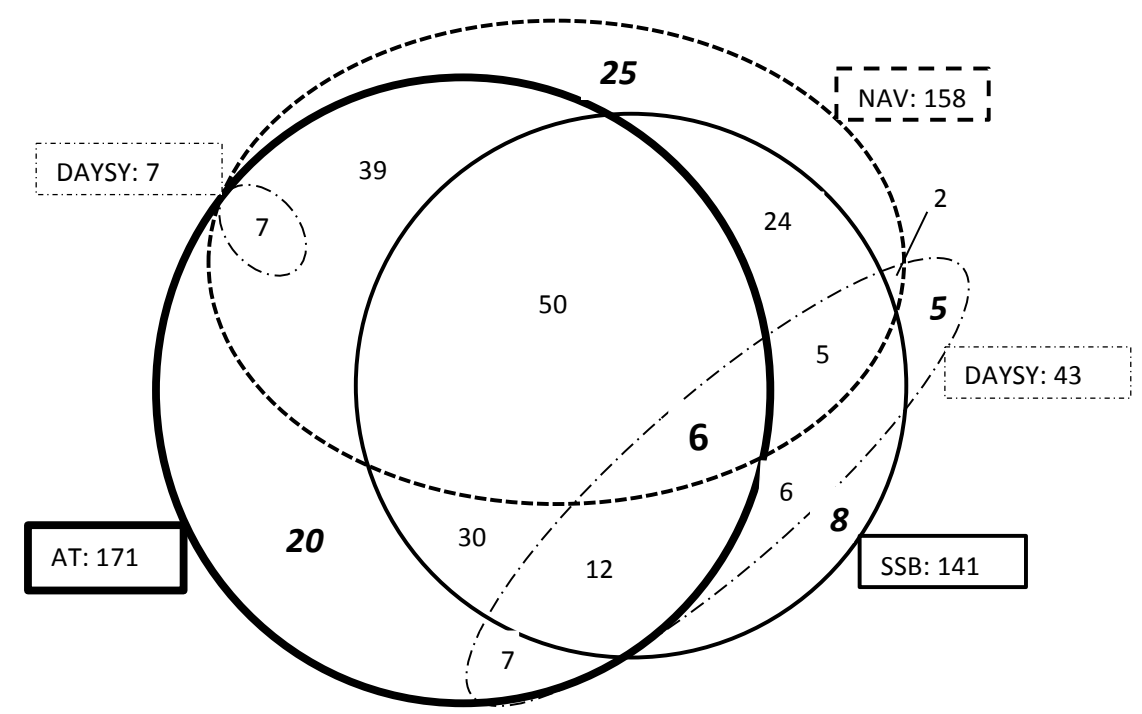

Figur 1. Arbeidsskadedødsfall 2000-2003 i landbasert virksomhet for personer bosatt i Norge (N=246), fordelt på datakildene der de var registrert. AT: Arbeidstilsynet, NAV: Arbeids- og Velferdsetaten, SSB: Dødsårsaksregisteret og DAYSY: forsikringsselskaper, Finans Norge. Registrert $i$ alle fire datakildene (uthevet) $(\mathrm{n}=6)$. Bare registrert i en datakilde (uthevet, kursiv) $(\mathrm{n}=58)$.

Tabell 1. Arbeidsskadedødsfall i landbasert virksomhet 20002003 for personer bosatt i Norge, etter hvor dødsfallet var registrert.

\begin{tabular}{|c|c|c|c|c|c|}
\hline \multicolumn{4}{|c|}{ Kilder for arbeidsskadedødsfall } & \multirow[b]{2}{*}{$\begin{array}{l}\text { Antall } \\
\text { unike }\end{array}$} & \multirow[b]{2}{*}{$\%$} \\
\hline $\begin{array}{l}\text { Arbeids- } \\
\text { tilsynet }\end{array}$ & $\begin{array}{l}\text { Dødsårsaks- } \\
\text { registeret } \\
\text { (SSB) }\end{array}$ & NAV & $\begin{array}{c}\text { DAYSY } \\
\text { (Finans Norge) }\end{array}$ & & \\
\hline \multirow[t]{5}{*}{20} & & & & 20 & \\
\hline & 8 & & & 8 & \\
\hline & & 25 & & 25 & \\
\hline & & & 5 & 5 & \\
\hline & \multicolumn{3}{|c|}{ Registrert $\mathrm{i}$ en kilde } & 58 & 24 \\
\hline 30 & \multirow[t]{3}{*}{30} & & & 30 & \\
\hline 39 & & 39 & & 39 & \\
\hline \multirow[t]{4}{*}{7} & & & 7 & 7 & \\
\hline & 24 & 24 & & 24 & \\
\hline & \multirow[t]{2}{*}{6} & & 6 & 6 & \\
\hline & & 2 & 2 & 2 & \\
\hline & \multicolumn{3}{|c|}{ Registrert $\mathrm{i}$ to kilder } & 108 & 44 \\
\hline 50 & \multirow[t]{2}{*}{50} & 50 & & 50 & \\
\hline 7 & & 7 & 7 & 7 & \\
\hline \multirow[t]{2}{*}{12} & 12 & & 12 & 12 & \\
\hline & 5 & 5 & 5 & 5 & \\
\hline \multicolumn{4}{|c|}{ Registrert $\mathrm{i}$ tre kilder } & 74 & 30 \\
\hline 6 & 6 & 6 & 6 & 6 & \\
\hline \multicolumn{4}{|c|}{ Registrert i fire kilder } & 6 & 2 \\
\hline \multicolumn{6}{|c|}{ Antall registrert $\mathrm{i}$ de fire kildene } \\
\hline 171 & 141 & 158 & 50 & 246 & 100 \\
\hline \multicolumn{6}{|c|}{$\%$ av totalt unike registrert $\mathrm{i}$ de fire kildene } \\
\hline 70 & 57 & 64 & 20 & 100 & \\
\hline
\end{tabular}

hadde opplysninger om 158 (64\%), Dødsårsaksregisteret om 141 (57\%) og DAYSY om 50 (20\%).

Andelen som overlevde mer enn 2 dager var større for de nye 32 enn for de 214, men forskjellen var ikke statistisk signifikant $(22 \%$ vs. $10 \%, p=0,063$, Fisher exact test, ensidig). Gjennomsnittsalder ved død var lavere (37 år vs 46 år, t-test to-sidig, $p=0,001$ ). Andelen dødsfall etter transportulykker med personbil (ICD-10 V40-V49) var høyere (41\% vs. $10 \%, \mathrm{p}<0,001$ Fisher exact test, to-sidig).
Av samtlige 246 døde var 51 (21\%) under 30 år. Insidens per 100000 sysselsatte per år var 2,8, og høyest for de eldste (>60 år) med 8,5 (figur 2). Hodeskade (ICD-10 S00-S09) var årsak til 30-35\% av dødsfallene i alle aldersgrupper.

Andelen transportulykker (ICD-10 V00-V99) var $40-45 \%$ i alle aldersgrupper, bortsett fra de eldste (>60 år) der fallulykker (W00-W19) utgjorde en like stor andel, omlag 30\% (figur 2). Med fire kilder identifiserte vi 96 dødsfall etter transportulykker, hvorav 68 hadde skadested «vei», noe som stort sett vil si trafikkulykker.

Den største undergruppen av transportulykkene $(n=36)$ var «annet landtransportkjøretøy» (ICD-10 V80-V89) (inkluderer kjøretøy benyttet på industriområder (V83) og i landbruk (V84)). De fleste (n=24) i denne gruppen hadde annet skadested enn vei. De to andre hovedgruppene var ulykker med personbil (ICD10 V40-V49) $(\mathrm{n}=34)$ og med tungt kjøretøy (ICD-10 V60-V69) $(\mathrm{n}=13)$. Alle hadde skadested vei. Arbeidstilsynet hadde registrert $61 \%$ av transportulykkene. Komplettheten varierte fra $32 \%$ for personbil til $100 \%$ for tungt kjøretøy (figur 3).

$165(67 \%)$ døde utenfor sykehus eller under transport til sykehus. For 16 (7\%) manglet opplysninger om dødssted. Andel dødsfall utenfor sykehus varierte med skadetype, høyest (79\%) etter transportulykker og lavere (51\%) etter fallulykker.

Insidensratene var høyest for næringsgruppene «bergverksdrift», «jord- og skogbruk», «transport» og «bygg og anlegg» (tabell 2). Den generelle dødsrisikoen tilsvarte 1-2 dødsfall per 1000 yrkesliv, men enkeltnæringer lå langt høyere. For bergverksdrift var dødsrisikoen 28 dødsfall per 1000 yrkesliv.

Statistisk sentralbyrå hadde sendt tilbakespørring til legen som utstedte dødsmeldingen i tre tilfeller. 


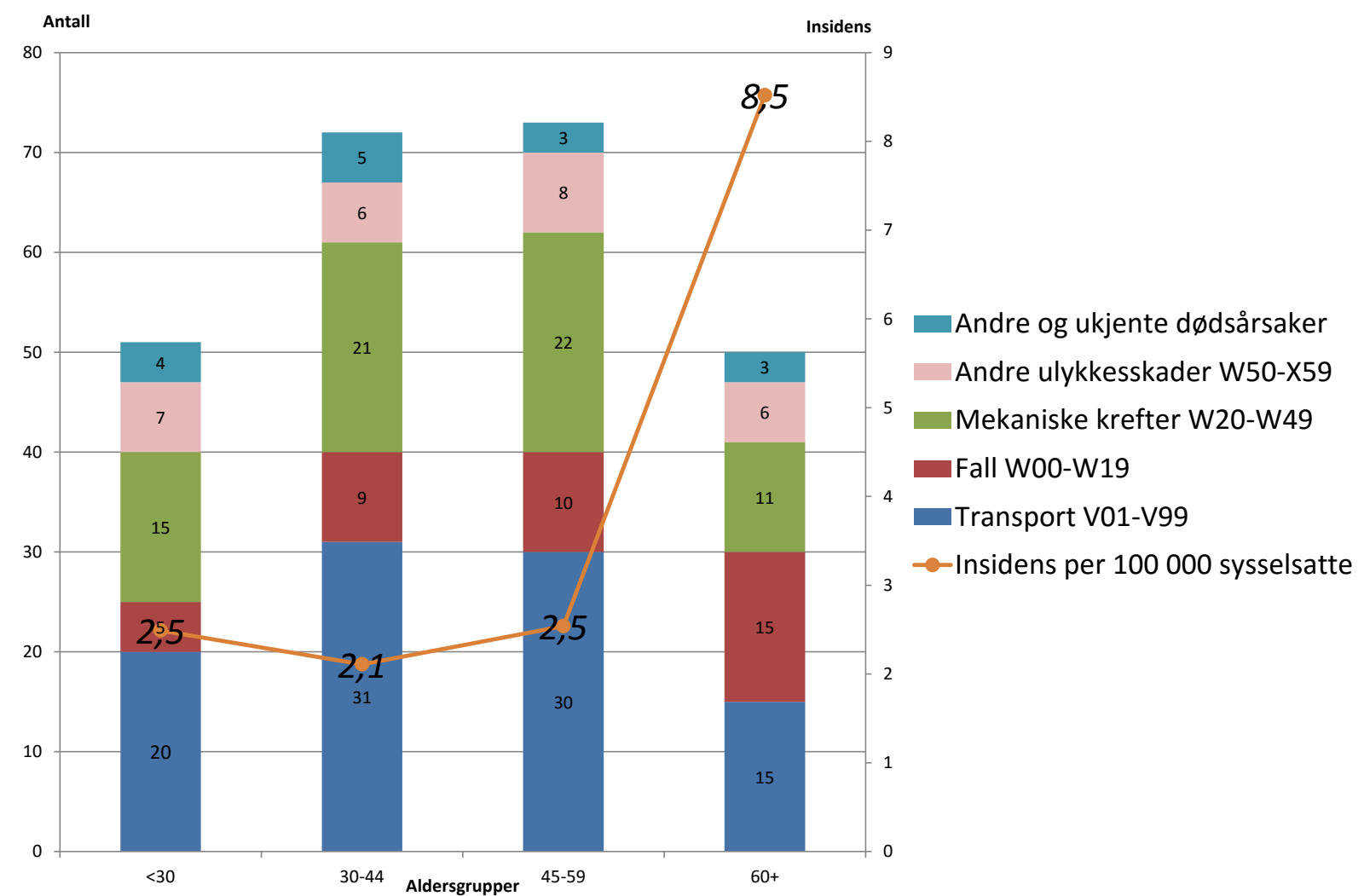

Figur 2. Arbeidsskadedødsfall 2000-2003 i landbasert virksomhet, bosatte i Norge. Ytre skadeårsak (ICD-10) og insidens per 100000 sysselsatte etter alder (10).

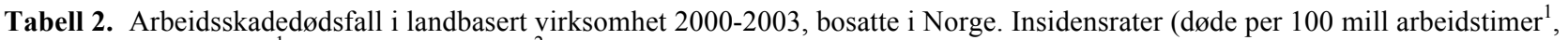
per 100000 sysselsatte $^{1}$ og per 1000 yrkesliv $^{2}$ ) etter næringsgruppe (SN2002).

\begin{tabular}{|c|c|c|c|c|c|c|c|}
\hline Næringsgrupper (SN2002) & $\begin{array}{c}\text { Døde } \\
2000-03\end{array}$ & $\begin{array}{l}\text { Mill. } \\
\text { timer }\end{array}$ & $\begin{array}{l}\text { Syssel- } \\
\text { satte } \\
(1000 \\
\text { pers })^{1} \\
\end{array}$ & $\begin{array}{l}\text { Årsverk } \\
(1000)^{1}\end{array}$ & $\begin{array}{l}\text { Døde per } \\
100 \text { mill. } \\
\text { timer }\end{array}$ & $\begin{array}{c}\text { Døde per } \\
100000 \\
\text { syssel- } \\
\text { satte }\end{array}$ & $\begin{array}{c}\text { Døde per } \\
1000 \\
\text { yrkesliv }^{2}\end{array}$ \\
\hline I alt & 246 & 12559,4 & 8916,8 & 7551,2 & 1,96 & 2,76 & 1,63 \\
\hline C Bergverksdrift $(10,12-14)$ & 9 & 27,5 & 16,5 & 16,2 & 32,73 & 54,55 & 27,78 \\
\hline A Jordbruk og skogbruk (01-02) & 41 & 562,4 & 289,7 & 251,1 & 7,29 & 14,15 & 8,16 \\
\hline I Transport og kommunikasjon $(60,62-64)$ & 41 & 879,0 & 567,6 & 520,4 & 4,66 & 7,22 & 3,94 \\
\hline F Bygge- og anleggsvirksomhet (45) & 27 & 910,2 & 565,9 & 542,0 & 2,97 & 4,77 & 2,49 \\
\hline E Kraft- og vannforsyning (40-41) & 3 & 106,0 & 66,9 & 63,6 & 2,83 & 4,48 & 2,36 \\
\hline D Industri $(15-37)$ & 45 & 1847,1 & 1169,0 & 1089,4 & 2,44 & 3,85 & 2,07 \\
\hline L Offentlig administrasjon, forsvar og sosialforsikring (75) & 17 & 1073,3 & 700,5 & 648,9 & 1,58 & 2,43 & 1,31 \\
\hline $\mathrm{B}, \mathrm{H}, \mathrm{J}$ Andre næringer $(05.02,55,65-67)$ & 10 & 708,3 & 507,9 & 420,7 & 1,41 & 1,96 & 1,19 \\
\hline G Varehandel, reparasjon av kjøretøyer (50-52) & 24 & 1816,4 & 1326,1 & 1076,5 & 1,32 & 1,81 & 1,11 \\
\hline K Forretningsmessig tjenesteyting, eiendomsdrift (70-74) & 11 & 1252,7 & 871,6 & 735,0 & 0,88 & 1,26 & 0,75 \\
\hline O Andre sosiale og personlige tjenester $(90-93)$ & 4 & 495,4 & 394,6 & 326,2 & 0,81 & 1,01 & 0,61 \\
\hline M Undervisning (80) & 5 & 977,3 & 720,2 & 608,5 & 0,51 & 0,69 & 0,41 \\
\hline N Helse- og sosialtjenester (85) & 8 & 1904,8 & 1720,3 & 1252,7 & 0,42 & 0,47 & 0,32 \\
\hline Z Uoppgitt & 1 & ---- & ---- & ---- & ---- & ---- & ---- \\
\hline
\end{tabular}

1) Mindre endringer i standarden for næringsgruppering siden tidligere publiserte resultater (2). Personer med midlertidig opphold, men bosatt utenfor Norge er inkludert (9). I følge SSB utgjorde de $1-2 \%$ av de sysselsatte i Norge i denne perioden, varierende med næringsgruppene (25).

2) Døde per 1000 yrkesliv $(50$ årsverk $)=($ Døde/1000 årsverk $) \cdot 50$.

\section{DISKUSJON}

Med informasjon fra NAV og DAYSY identifiserte vi 32 arbeidsskadedødsfall med skadeår 2000-2003 i tillegg til de 214 fra Arbeidstilsynet og Dødsårsaks- registeret, i alt 246 i landbasert virksomhet blant bosatte i Norge. Arbeidstilsynet hadde registrert 171 (70\%) av disse. Det totale antallet arbeidsskadedødsfall basert på disse fire kildene $(\mathrm{n}=246)$ var identisk med vårt tidligere estimat basert på to kilder $(n=246)(2)$. 


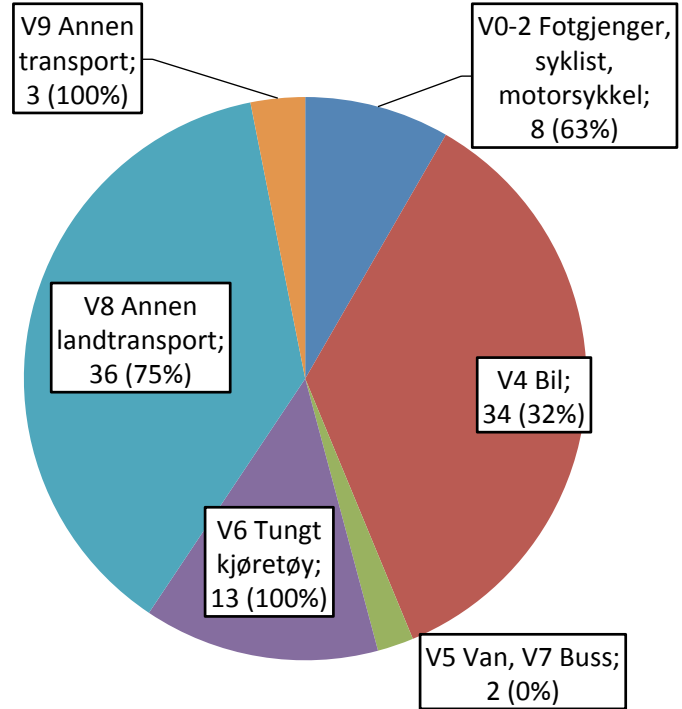

Figur 3. Arbeidsskadedødsfall etter transportulykker (ICD10 V01-99) 2000-2003 i landbasert virksomhet, bosatte i Norge, etter transportmiddel $(\mathrm{N}=96)$. Totalt antall basert på fire kilder og andel (\%) som var registrert av Arbeidstilsynet.

Antakelsen om at NAV/DAYSY ville fange opp flere dødsfall med lang overlevelsestid ble ikke bekreftet, men andelen som overlevde $>2$ dager var høyere for de nye 32 dødsfallene (grensesignifikant på 5\% nivå). Dødsfall lang tid etter ulykken kan være underrapportert $\mathrm{i}$ alle fire kilder. Dødsårsaksregisteret er trolig den eneste av kildene som potensielt kan fange opp flere slike dødsfall. Arbeidstilsynets registreringssystem er mindre egnet, fordi det er basert på arbeidsgivers/politiets varsel umiddelbart etter skaden. Det fanger ikke opp om skaden senere fører til døden. Mange alvorlige skader blir heller ikke meldt til Arbeidstilsynet (11).

De 32 nye dødsfallene hadde lavere gjennomsnittsalder enn de 214, og andelen som skyldtes ulykker med personbil (ICD-10 V40-V49) var høyere. Fordi antallet var lite, endret likevel ikke dette vesentlig på risikobildet basert på Arbeidstilsynets register og Dødsårsaksregisteret.

I den totale populasjonen $(\mathrm{n}=246)$ var transportulykker den største kategorien av ytre dødsårsaker. Vi har tidligere vist at underregistreringen i Arbeidstilsynet var størst for denne gruppen (2). Differensiering etter undergrupper viser at underregistreringen først og fremst gjaldt ulykker med personbil (ICD-10 V40-V49). Det kan ha ført til at forebyggende tiltak på dette området er blitt for lavt prioritert i Arbeidstilsynet (12).

Underregistrering av dødsfall etter ulykker med personbil (ICD-10 V40-V49) kan skyldes at Arbeidstilsynet ofte er avhengig av informasjon fra politiet. Politiet rykker ut til hendelser med alvorlig personskade og død og skal varsle Arbeidstilsynet om arbeidsrelaterte hendelser. Politiet kan ha vansker med å identifisere trafikkulykker med personbil som arbeidsrelaterte hvis de ikke involverer yrkessjåfør eller tjenestekjøretøy.

NAV hadde registrert 158 (64\%) av samtlige 246 dødsfall. Komplettheten ville vært lavere om vi bare hadde inkludert godkjente «yrkesskader». «Yrkesskade» er et juridisk begrep som omfatter et mindre utvalg dødsfall enn Arbeidstilsynets kriterier for registrering (2), og det som internasjonalt er definert som «fatal occupational injury» (7). Manglende melding fra arbeidsgiver kan delvis forklare hvorfor NAV ikke hadde registrert flere dødsfall. Vi undersøkte om omleggingen av IKT-rutiner i 2000-2001 påvirket dekningsgraden, men den var henholdsvis 58 og $72 \%$ de to årene.

DAYSY hadde informasjon om $50(20 \%)$ av samtlige 246 dødsfall. Finans Norge får ikke data fra alle forsikringsselskap. I 2000-2003 mottok de data fra norske selskap med en samlet markedsandel for yrkesskadeforsikring på $81 \%$ i landbaserte virksomheter (Kari Mørk, Finans Norge, i brev av 19.01.2015). Markedsandelen var enda lavere (50-60\%) for risikoutsatte næringer som bygg og anlegg og industri. Dødsfall ved bruk av motorkjøretøy blir vanligvis ikke registrert som yrkesskade fordi motorvognforsikringen er mer fordelaktig for de etterlatte. Dekningsgraden for dødsfall etter transportulykker var imidlertid omtrent som for øvrige kategorier ( $18 \%$ vs. $20 \%)$.

Verken NAV eller Finans Norge hadde informasjon om hvor mange etterlatte som ble tilstått trygd eller forsikring etter arbeidsskadedødsfall 2000-2003. Vi vet derfor ikke om det har vært underforbruk av ytelser etter arbeidsskadedødsfall slik det er påvist ved yrkessykdom og -skader $(13,14)$.

Arbeidstilsynets statistikk etter 2003 er vanskelig å validere fordi fødselsnummer ikke blir registrert systematisk. Sammenlikning med andre kilder på individnivå blir derfor vanskelig. Vi har imidlertid sett på Arbeidstilsynets nyeste registreringer av dødsfall etter «sammenstøt/påkjørsel» og «annet - trafikkulykke» som vi antar omtrent tilsvarer transportulykker (ICD10 (V01-V99)). I 2013-14 registrerte Arbeidstilsynet til sammen 20 slike dødsfall (Bodil Aamnes Moestue, Arbeidstilsynet, personlig meddelelse). Hvis underrapporteringen i 2013-2014 var uforandret fra 2000$2003(61 \%)$, ville det virkelige årsgjennomsnittet bli om lag 16 dødsfall $((100 \bullet 20) /(61 \bullet 2))$. Hvis rapporteringen er blitt bedre, slik Arbeidstilsynet antar, var det virkelige årsgjennomsnittet lavere. Uansett var det betydelig lavere enn årsgjennomsnittet 2000-2003 på 24 (96/4), beregnet på grunnlag av identifiserte dødsfall etter transportulykker fra fire kilder. Det tyder på en risikoreduksjon for denne typen ulykker. Siden totalantallet dødsfall som Arbeidstilsynet registrerer ikke er redusert, betyr det at antallet må være økt for andre kategorier på grunn av økt risiko eller bedre rapportering. Men Arbeidstilsynets statistikk forteller ikke om det er en reell risikoøkning $\mathrm{i}$ andre undergrupper. Eksempelet viser at Arbeidstilsynet vanskelig kan overvåke risikoutviklingen med dagens statistikk uten kunnskap om omfang og fordeling av underrapportering.

Statistisk sentralbyrå (SSB) har i flere tiår registrert ulykkesdødsfall i inntektsgivende arbeid (arbeids- 
skadedødsfall) som en del av offisiell dødsårsaksstatistikk. De publiserte denne statistikken fram til 2009 (15,16). Folkehelseinstituttet har overtatt ansvaret for utarbeidelse og publisering av nasjonal dødsårsaksstatistikk, men publiserer ikke statistikk over ulykkesdødsfall i inntektsgivende arbeid eller i andre aktiviteter. Det pågår siden 2009 et interdepartementalt strategisamarbeid for å forebygge ulykker med personskade. Det har som formål å tallfeste mål for ulykkesreduksjon ved hjelp av pålitelig statistikk (17). Videreføring av statistikken over ulykkesdødsfall med forbedret registrering i Dødsårsaksregisteret, vil være et naturlig sted å begynne arbeidet med en slik tallfesting (2). Potensielt er ulykkesdødsfall den mest pålitelige risikoindikatoren for alvorlig personskade både $\mathrm{i}$ arbeidslivet og ellers i samfunnet.

Arbeidstilsynet hadde størst kompletthet av de undersøkte kildene (70\%). Arbeidstilsynet kan innhente opplysninger om arbeidsulykker med personskade og opplysning om yrke, næringsgruppe og arbeidsstyrkestatus på skadetidspunktet. Insidensratene for bergverk 2000-2003 (tabell 2) viser hvordan statistikken kan brukes til å identifisere spesielt utsatte grupper. Mulighetene ville være betydelig større hvis Arbeidstilsynet registrerte yrke i tillegg til næringsgruppe.

Dødsårsaksregisteret hadde bare identifisert $57 \%$ av de 246 dødsfallene som arbeidsskadedødsfall. De øvrige dødsmeldingene manglet informasjon som kunne identifisere arbeidsskadedødsfall. Manglende informasjon om dødsårsak (herunder aktivitet og skadested som er viktig for identifisering av arbeidsskadedødsfall) kan innhentes ved tilbakespørring til lege som utstedte dødsmeldingen. Dette kan i neste omgang også bedre kvaliteten av innsendte dødsmeldinger. Tilbakespørring er en anbefalt metode internasjonalt for å revidere og kvalitetssikre dødsårsaksstatistikk $(6,18,19)$. Tilbakespørring var nesten ikke benyttet ved de 246 arbeidsskadedødsfallene.

Arbeidstilsynets og Dødsårsaksregisterets løpende registreringer kan med kvalitetsforbedringer gi en mer pålitelig oversikt over dødsrisikoen $\mathrm{i}$ arbeidslivet enn vi har i dag, med mulighet til å følge risikoutviklingen over tid og analysere variasjoner etter yrke, næring, skadens medisinske art (ICD-10 kap XIX) og skadens ytre årsak (ICD-10 kap XX).

En utredning om statistikk over arbeidsulykker anbefaler samarbeid mellom NAV, SSB og Arbeidstilsynet (20). Utredningen behandler ikke dødsfall spesielt, men angir at Arbeidstilsynet registrerer 100\% av dødsulykkene. Dette stemmer ikke med våre funn for perioden 2000-2003 (2). En utredning for Helse- og Omsorgsdepartementet foreslår en indikator for dødelighet i arbeidslivet basert på informasjon fra Statens Arbeidsmiljøinstitutt (STAMI), SSB og eventuelt Dødsårsaksregisteret (21). Ettersom STAMI og SSB ikke selv registrerer arbeidsskadedødsfall, vil indikatorens kvalitet avhenge av kvaliteten for kildene vi har undersøkt: Arbeidstilsynet (eventuelt andre relevante tilsynsmyndigheter), Dødsårsaksregisteret og NAV.
Supplering av Arbeidstilsynets data om dødsfall med data fra NAV ville for 2000-2003 identifisert 227 eller $92 \%$ av de 246 vi identifiserte med fire kilder (tabell 1, figur 1). Selv om komplettheten i studieperioden var mindre i Dødsårsaksregisteret enn i NAV, er det Dødsårsaksregisteret som best kan supplere informasjonen i Arbeidstilsynets register. Dødsårsaksregisteret er ut fra sitt formål den kilden som potensielt kan oppnå størst kompletthet. Informasjonen om skadene (diagnose, skadetype) vil også ha bedre kvalitet enn i et administrativt register (NAV). Registreringene i NAV vil i hovedsak være begrenset til dødsfall som blir meldt av arbeidsgiver og som juridisk blir godkjent som «yrkesskade».

At $67 \%$ av alle dødsfall inntraff før den skadde nådde sykehus, bekrefter viktigheten av primærforebygging. En studie av alle skadedødsfall (ICD-10 V01Y89) i aldersgruppen 16-66 år i Norge 1998-2007 viste en enda høyere andel dødsfall utenfor sykehus (78\%), men studien omfattet også selvpåført skade (22). Andelen som døde utenfor sykehus etter transportulykker $(75 \%)$ og fallulykker (51\%) var omtrent som i vår studie. Forskjeller i andelen som dør utenfor sykehus etter ulike ytre skadeårsaker viser forskjeller i skadepotensialet. Forskjeller i forholdstallet død/alvorlig skade viser noe av det samme. En studie av arbeidsskadedata fra Nederland viste at det var flere personskader med varig mén for hvert dødsfall etter fallulykker enn etter transportulykker (23). Forholdstallet $\mathrm{død}$ /alvorlig skade har betydning når man bruker dødsrisikoen som indikator for alvorlig personskaderisiko.

Dødsfall hos arbeidstakere som ikke er bosatt i Norge, men som arbeider her, er en viktig del av risikobildet i norsk arbeidsliv og inkluderes i Arbeidstilsynets statistikk. Slike dødsfall er ikke behandlet i denne studien fordi SSBs dødsårsaksstatistikk var begrenset til personer bosatt i Norge, (24). I perioden 2000-2003 utgjorde slike dødsfall 7\% av Arbeidstilsynets registreringer og i 2011-14 19\% $(1,2)$. Riktig registrering av slike dødsfall krever spesielle metoder, for eksempel samarbeid med andre lands ambassader. Risikoestimatene må ta hensyn til omfanget av deltakelsen $\mathrm{i}$ arbeidslivet. I følge SSB utgjorde personer med midlertidig opphold, men bosatt utenfor Norge, 1$2 \%$ av de sysselsatte i Norge i denne perioden, varierende med næringsgruppe (25).

Mens antall drepte $\mathrm{i}$ arbeidslivet $\mathrm{i}$ følge Arbeidstilsynet har vært nokså uendret siden 2001, er tallet på trafikkdrepte siden 2005 redusert med en tredel fra ca. 300 til ca. 200 per år $(1,26)$. Samferdselsmyndighetene har lenge arbeidet systematisk med å forebygge alvorlige personskader i trafikken. Statistikk, ulykkesgransking og -analyser har vært viktige hjelpemidler. Erfaringene har overføringsverdi til arbeidslivet.

Takk til Gunvor Østevold (Dødsårsaksregisteret) og Gunnar Claus (arbeidsmarkedsstatistikk) $i$ Statistisk sentralbyrå, Lillian Brenne og Jostein Ellingsen i NAV og Steinar Holm og Kari Mørk i Finans Norge, for god hjelp. 


\section{REFERANSER}

1. Moestue BA, Søberg M, Winge S. Arbeidsskadedødsfall i Norge. Utviklingstrekk 2009-2014. Kompass Tema nr. 3. Trondheim: Arbeidstilsynet, 2015.

2. Wergeland E, Gjertsen F, Lund J. Arbeidsskadedødsfall blir underrapportert. Tidsskr Nor Legeforen 2009; 129; 981-6.

3. Samant Y, Parker D, Wergeland E, et al. Estimating work-related amputations in the Norwegian manufacturing sector: a 10-year retrospective study based on two-source capture-recapture method. Int J Occup Environ Health 2012; 18: 292-8.

4. Bendixen A, Hansen IS, Morild I, et al. Dødsfall som følgje av vald og ulukker i Hordaland 2003-4. Tidsskr Nor Legeforen 2014; 134: 27-30.

5. Lund J, Bjerkedal T, Gravseth HM, et al. A two step medically based injury surveillance system - experiences from the Oslo injury register. Accid Anal Prev 2004; 36: 1003-17.

6. Gjertsen F. Assessing the comparability of injury mortality statistics with reference to suicide, classification systems, and firearms legislation. Ph.D. dissertation. Oslo: Faculty of Medicine, University of Oslo, 2015.

7. Statistics of occupational injuries. Report III. Sixteenth International Conference for Labour Statisticians. Geneva: ILO, 1998.

8. DAYSY-rapport 2015: Årsaksstatistikk i yrkesskadeforsikring. Oslo: Finans Norge, 2015.

9. Statistikkbanken. Årlig nasjonalregnskap: Lønn, sysselsetting og produktivitet etter næring. Tabell 09174. www.ssb.no/statistikkbanken (8.6.2015).

10. Statistikkbanken. Sysselsatte etter kjønn og alder. Tabell 03781. www.ssb.no/statistikkbanken (10.6.2015).

11. Gravseth HM, Wergeland E, Lund J. Underrapportering av arbeidsskader til Arbeidstilsynet. Tidsskr Nor Legeforen 2003; 123: 2057-9.

12. Nævestad T-O, Phillips R, Elvebakk B, et al. Work-related accidents in Norwegian road, sea and air transport: prevalence and risk factors. TØI Report 1428/2015. Oslo: Transportøkonomisk institutt, 2015.

13. Bratt U, Leira HL. Lov om yrkesskadeforsikring, en forbedring for de skadelidte? Tidsskr Nor Legeforen 1997; 117: 207-11.

14. Wergeland E, Bjerkedal T, Andersen A, et al. Bruk av yrkesskadetrygd ved yrkessykdom. Tidsskr Nor Legeforen 1997; 117: 211-6.

15. Gjertsen F. Dødelighet ved ulykker 1956-1988. Rapporter 92/8. Oslo-Kongsvinger: Statistisk sentralbyrå, 1992.

16. Statistikkbanken. Tabell: 03516: Dødsulykker, etter skadested og aktivitet (1996-2009). Oslo-Kongsvinger: Statistisk sentralbyrå. www.ssb.no/statistikkbanken (29.07.15).

17. Stortingsmelding 19 (2014-15). Folkehelsemeldingen - Mestring og muligheter, s. 130.

18. Johansson LA. Targeting non-obvious errors in death certificates. Ph. D. dissertation. Uppsala: Faculty of Medicine, Uppsala University, 2008.

19. International Statistical Classification of Diseases and Related Health Problems. Tenth Revision. Volume 2. Instruction manual. Geneva: World Health Organization, 1993.

20. Dal AC, Kjelvik J, Westvold T, Jensen A. Utredning om mulighet for ny statistikk over arbeidsulykker og yrkessykdommer basert på data fra Arbeids- og Velferdsforvaltningen (NAV). Notater 2008/25.

21. Indikatorer på skadefeltet. Oslo: Folkehelseinstituttet, 2014.

22. Kristiansen T, Lossius HM, Rehn M, et al. Epidemiology of trauma: A population-based study of geographical risk factors for injury deaths in the working-age population of Norway. Injury 2014; 45: 23-30.

23. Bellamy L. Exploring the relationship between major hazard, fatal and non-fatal accidents through outcomes and causes. Safety Science 2015; 7: 93-103.

24. Gjertsen F. Dødsårsaksregisteret - en viktig kilde til medisinsk forskning. Tidsskr Nor Legeforen 2002; 122: 2551-4.

25. Statistikkbanken. Tabell 2. Lønnstakere ikke registrert bosatt fordelt etter næring. 4. kvartal 2003-4. kvartal 2005. Oslo-Kongsvinger: Statistisk sentralbyrå. https:/www.ssb.no/arbeid-og-lonn/statistikker/kortsys/aar/ 2006-06-20 (15.09.2015).

26. Nasjonal transportplan 2024-2023. St.meld nr. 26, 2012-2013 2.1.3.2. s. 31. 